\title{
Immunotherapy improves sleep and cognitive impairment in anti-IgLON5 encephalopathy
}

Valerio Brunetti, MD, Giacomo Della Marca, MD, PhD, Gregorio Spagni, MD, and Raffaele lorio, MD, PhD

Neurol Neuroimmunol Neuroinflamm 2019;6:e577. doi:10.1212/NXI.0000000000000577

Autoimmune encephalopathy associated with immunoglobulin G (IgG) autoantibodies binding to IgLON5 is characterized by a sleep disorder that includes sleep-disordered breathing and parasomnia, accompanied by gait disturbance, bulbar symptoms, dysautonomia, and cognitive decline. ${ }^{1}$ The effect of immunotherapy in patients with anti-IgLON5 disease remains unclear.

We herein report the polysomnographic findings and the clinical and immunologic characteristics of a patient with IgLON5-IgG before and after 1 year of immunotherapy.

\section{Case report}

A 69-year-old man was admitted to our institution for excessive daytime sleepiness associated with complex stereotyped movements. Three years before, the patient was admitted to the intensive care unit for respiratory failure due to vocal cords palsy in adduction and underwent tracheotomy; a pacemaker was placed after 2 episodes of severe bradycardia. Five years before, he experienced erectile dysfunction and constipation; then, his wife reported complex movements during sleep.

Video-polysomnography revealed finalistic movements mimicking daily activities (oneiric stupor), such as eating, at sleep onset and in the second half of the night (video 1). Electroencephalographic activity during those periods was characterized by a double peak of frequency at 5 and $10 \mathrm{~Hz}$; moreover, K-complex and sleep spindles were absent. This undifferentiated NREM sleep was followed by a poorly structured N2 sleep, with rare K-complex and sleep spindles and then by normal N2 sleep and few epochs of N3 sleep. REM sleep was undetectable (figure, A). Neurologic examination revealed mild gait ataxia. The patient had an open tracheostomy, and he was on assisted ventilation during the night. He had cognitive impairment and needed help for most activities of daily living (ADL). Neuropsychological examination showed a Mini Mental Status Examination (MMSE) score of 24/30, a prevalent impairment of visuospatial functions: Multiple Features Target Cancellation (MFTC) accuracy was 0.89, number of false recognition was 4, and time of execution was 240 seconds; the accuracy of the Rey Word Recognition Test (RWRT) was 0.78, and forward spatial span was 3. Anti-IgLON5 encephalopathy was suspected, and IgLON5-IgG was tested by indirect immunofluorescence on mouse brain and cell-based assays, as previously described. ${ }^{2}$ IgLON5-IgG was detected in both patient's serum (titer: 1:5,000) and CSF (1:100). The patient's human leukocyte antigen (HLA) typing revealed HLA-DQB1*05:01 and HLA-DRB1*10:01. Brain MRI and 99mTc-hexamethylpropyleneamine oxime (HMPAO)-single photon emission computed tomography were normal. The patient was treated with monthly IV immunoglobulins $(0.4 \mathrm{~g} / \mathrm{kg} / \mathrm{d}$ for 5 days $)$, prednisone $(0.8 \mathrm{mg} / \mathrm{kg})$, and azathioprine $(2 \mathrm{mg} / \mathrm{kg})$. Subsequently, he progressively improved, showing a reduction of daytime sleepiness and of motor activation during the sleep, as reported by the spouse. After 1 year of immunotherapy, home-based unattended PSG showed a partial improvement of sleep architecture: REM sleep was present and characterized by physiological muscle atonia. Undifferentiated NREM sleep was present exclusively in the second half of the night, but with less sustained muscular activation (figure, B). Despite the improvement of the sleep

\author{
Correspondence \\ Dr. Iorio \\ raffaele.iorio@policlinicogemelli.it
}

MORE ONLINE

- Video

From the Institute of Neurology (V.B., G.D.M., G.S., R.I.), Università Cattolica del Sacro Cuore; and Fondazione Policlinico Universitario “A. Gemelli" IRCCS (G.D.M., R.I.), Roma, Italy. Go to Neurology.org/NN for full disclosures. Funding information is provided at the end of the article.

The Article Processing Charge was funded by the authors.

This is an open access article distributed under the terms of the Creative Commons Attribution-NonCommercial-NoDerivatives License 4.0 (CC BY-NC-ND), which permits downloading and sharing the work provided it is properly cited. The work cannot be changed in any way or used commercially without permission from the journal. 


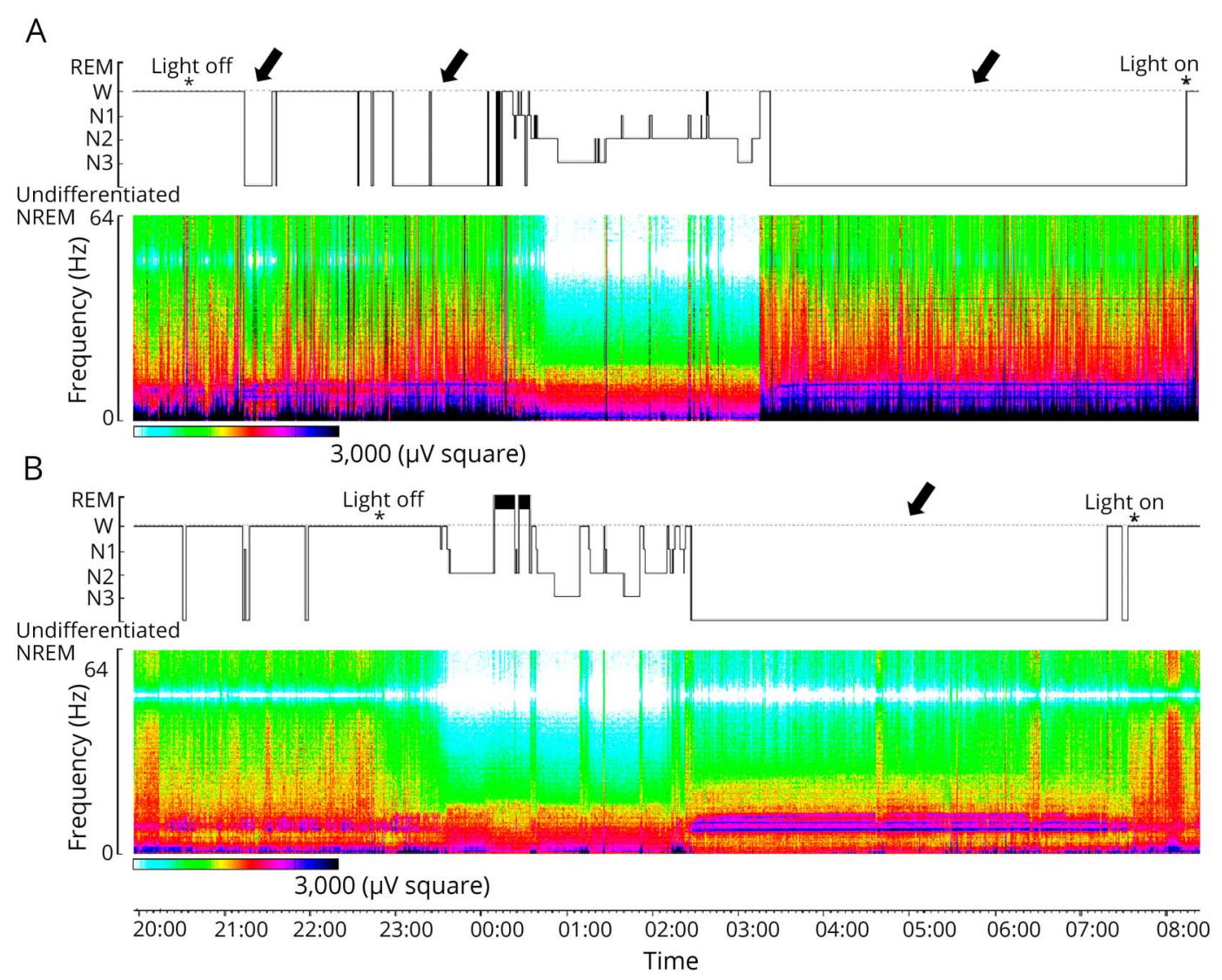

(A) Hypnogram and DSA before the treatment. Hypnogram: undifferentiated NREM sleep is prevalent, particularly at the sleep onset and in the second half of the night (black arrows); REM sleep is not detectable. DSA showing the power spectrum of electroencephalographic frequencies (0-64 Hz) in bipolar C3-O1 derivation: undifferentiated NREM sleep is characterized by a continuous activity with a double peak of frequency at 5 and $10 \mathrm{~Hz}$. (B) Hypnogram and DSA after 1 year of immunotherapy. Hypnogram: an NREM-REM cycle is present. Undifferentiated NREM sleep is still present in the second half of the night (black arrow). DSA: undifferentiated NREM sleep is still characterized by a continuous activity with a double peak of frequency at 5 and $10 \mathrm{~Hz}$. DSA = density spectral array.

organization and the reappearing of the REM sleep, we did not observe a significant reduction in the percentage of undifferentiated NREM sleep (e-table, links.lww.com/NXI/ A117). The neurologic examination showed a resolution of gait ataxia. An improvement of cognitive functions was observed: the MMSE score was 30/30; MFTC accuracy was 0.96, number of false recognition was 5 , and time of execution was 91 seconds; the accuracy of RWRT was 0.85 , and forward spatial span was 6 . These findings were consistent with an improvement in the domains of visual spatial attention, working memory, and episodic memory. The patient regained independence in the ADL. IgLON5 antibodies were still detected in both serum $(1: 1,000)$ and CSF (1:10), but with a lower titer.

\section{Discussion}

The effect of 1 year of immunotherapy in a patient with anti-IgLON5 encephalopathy is herein documented by polysomnography and neuropsychological examination. AntiIgLON5 disease involves prevalently the brain stem and hypothalamus, 2 structures that are crucial for wake-NREMREM sleep alternation. ${ }^{3}$ In fact, wake is promoted by the ascending reticular activating system located in the brainstem and basal forebrain. Conversely, median and ventrolateral preoptic nuclei of the hypothalamus are considered the generators of slow-wave sleep; REM-generator neurons are sited in pedunculopontine and laterodorsal tegmental nuclei. ${ }^{4}$ The disease is characterized by autoantibodies binding IgLON5, a neuronal cell adhesion molecule, and by the neuropathologic evidence of Tau aggregates, suggesting a combined autoimmune and neurodegenerative pathogenesis. Evidence is compelling that IgLON5-IgG has pathogenic potential. ${ }^{5}$ The effect of immunotherapy in anti-IgLON5 encephalopathy is still debated, with some patients being poorly responsive to immunotherapy ${ }^{1,6}$ and others showing a good response. ${ }^{7}$

Our observation suggests that sustained immunotherapy can improve sleep disorder and cognitive impairment in antiIgLON5 disease. The improvement of neurologic symptoms was associated with a decrease in IgLON5-IgG titer. Further studies are needed to develop a standardized therapy regimen for this severe disease.

\section{Author contributions}

V. Brunetti: acquisition, analysis, and interpretation of data and drafting of the manuscript. G.D. Marca and G. Spagni: 
data acquisition and analysis. R. Iorio: study concept and design; acquisition, analysis, and interpretation of data; and critical revision of the manuscript for important intellectual content.

\section{Study funding}

No targeted funding reported.

\section{Disclosure}

The authors report no relevant disclosures. Go to Neurology. org/NN for full disclosures.

\section{Publication history}

Received by Neurology: Neuroimmunology \& Neuroinflammation January 13, 2019. Accepted in final form March 21, 2019.

\section{References}

1. Sabater L, Gaig C, Gelpi E, et al. A novel non-rapid-eye movement and rapid-eyemovement parasomnia with sleep breathing disorder associated with antibodies to IgLON5: a case series, characterisation of the antigen, and post-mortem study. Lancet Neurol 2014;13:575-586.

2. Iorio R, Damato V, Evoli A, et al. Clinical and immunological characteristics of the spectrum of GFAP autoimmunity: a case series of 22 patients. J Neurol Neurosurg Psychiatry 2018;89:138-146.

3. Gelpi E, Höftberger R, Graus F, et al. Neuropathological criteria of anti-IgLON5related tauopathy. Acta Neuropathol 2016;132:531-543.

4. Scammell TE, Arrigoni E, Lipton JO. Neural circuitry of wakefulness and sleep. Neuron 2017;93:747-765.

5. Sabater L, Planagumà J, Dalmau J, Graus F. Cellular investigations with human antibodies associated with the anti-IgLON5 syndrome. J Neuroinflammation 2016; 13:226.

6. Gaig C, Graus F, Compta Y, et al. Clinical manifestations of the anti-IgLON5 disease. Neurology 2017;88:1736-1743.

7. Honorat JA, Komorowski L, Josephs KA, et al. IgLONS antibody: neurological accompaniments and outcomes in 20 patients. Neurol Neuroimmunol Neuroinflamm 2017;4:e385. doi: 10.1212/NXI.0000000000000385. 


\title{
Neurology \\ Neuroimmunology \& Neuroinflammation
}

\author{
Immunotherapy improves sleep and cognitive impairment in anti-IgLON5 \\ encephalopathy \\ Valerio Brunetti, Giacomo Della Marca, Gregorio Spagni, et al. \\ Neurol Neuroimmunol Neuroinflamm 2019;6; \\ DOI 10.1212/NXI.0000000000000577
}

This information is current as of May 21, 2019

\section{Updated Information \& \\ Services}

References

Citations

Subspecialty Collections

Permissions \& Licensing

Reprints including high resolution figures, can be found at:

http://nn.neurology.org/content/6/4/e577.full.html

This article cites 7 articles, 1 of which you can access for free at: http://nn.neurology.org/content/6/4/e577.full.html\#\#ref-list-1

This article has been cited by 3 HighWire-hosted articles: http://nn.neurology.org/content/6/4/e577.full.html\#\#otherarticles

This article, along with others on similar topics, appears in the following collection(s):

Autoimmune diseases

http://nn.neurology.org//cgi/collection/autoimmune_diseases Encephalitis

http://nn.neurology.org//cgi/collection/encephalitis

Parasomnias

http://nn.neurology.org//cgi/collection/parasomnias

Information about reproducing this article in parts (figures,tables) or in its entirety can be found online at:

http://nn.neurology.org/misc/about.xhtml\#permissions

Information about ordering reprints can be found online:

http://nn.neurology.org/misc/addir.xhtml\#reprintsus

Neurol Neuroimmunol Neuroinflamm is an official journal of the American Academy of Neurology.

Published since April 2014, it is an open-access, online-only, continuous publication journal. Copyright

Copyright $\odot 2019$ The Author(s). Published by Wolters Kluwer Health, Inc. on behalf of the American

Academy of Neurology.. All rights reserved. Online ISSN: 2332-7812.

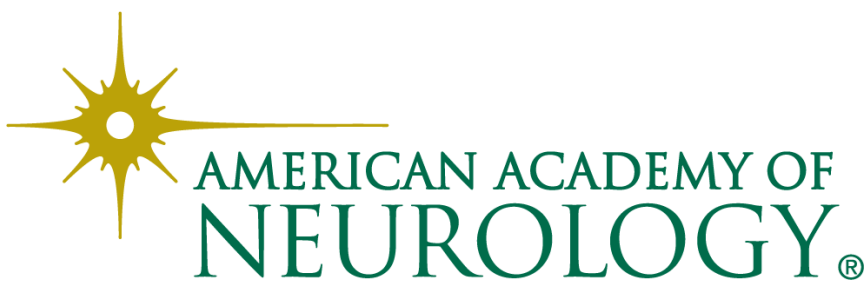

